\title{
INDAGAÇÕES SOCIOAMBIENTAIS E A COVID-19
}

\author{
Aline Matos Santos ${ }^{1}$ \\ Daiane da Paixão de Jesus Dias² \\ Fernanda Jesus Silva ${ }^{3}$ \\ Jerline dos Santos Carvalho ${ }^{4}$ \\ Maria Vanessa de Assis Oliveira Lima ${ }^{5}$ \\ Paula da Silva Damião6 \\ Vanessa Damasceno de Jesus ${ }^{7}$ \\ Valdemiro Lopes Marinho ${ }^{8}$
}

Resumo: O século 21, e mais precisamente o ano de 2020, vem sendo tomado por uma guerra silenciosa, que tem deixado mais vítimas que as lutas armadas entre países rivais. Surge de várias partes do mundo gritos por socorro. O animal não humano agradece por poder respirar melhor. Este, não necessita do animal humano para seguir o seu ciclo. Ante tal situação, e com base nos princípios da Educação Ambiental, este estudo estabelece um diálogo com professores e estudantes da Universidade do Estado da Bahia (UNEB) sobre as questões socioambientais e a COVID-19, realizado a partir da aplicação de uma enquete, bem como a busca do fortalecimento do Grupo de Estudo em Educação e Meio Ambiente (GEMA), que atua junto às escolas e à comunidade.

Palavras-chave: Meio Ambiente; COVID-19; Educação; GEMA.

\footnotetext{
1 Estudante de Administração e membro do GEMA na UNEB.

E-mail: alinem12.am@hotmail.com

2 Estudante de Geografia e membro do GEMA na UNEB. E-mail: daianedapaixao@hotmail.com

${ }^{3}$ Estudante de Pedagogia e membro do GEMA na UNEB.

E-mail: nanda_silva003@hotmail.com

${ }^{4}$ Estudante de Pedagogia e membro do GEMA na UNEB. E-mail: jerlinesc18@gmail.com

${ }^{5}$ Estudante de Pedagogia e membro do GEMA na UNEB.

E-mail: mariavanessa.236@gmail.com

${ }^{6}$ Estudante de Pedagogia e membro do GEMA na UNEB. E-mail: paula.damiao@yahoo.com.br

7 Estudante de Geografia e membro do GEMA na UNEB. E-mail: nyssajesus@gmail.com

8 Professor e coordenador do GEMA na UNEB. E-mail: miromarinho60@gmail.com
} 
Abstract: The 21st century, and more precisely the year 2020, has been overtaken by a silent war, which has left more victims than the armed struggles between rival countries. Screams for help arise from various parts of the world. The non-human animal is grateful to be able to breathe better. It does not need the human animal to follow its cycle. Faced with this situation, and based on the principles of environmental education, this study establishes a dialogue with professors and students of the University of the State of Bahia (UNEB) on socio-environmental issues and COVID-19, carried out through the application of a survey, as well as the search for the strengthening of the Education and Environment Study Group (GEMA), which works with schools and the community.

Keywords: Environment; COVID-19; Education; GEMA.

\section{Introdução}

Neste início de Século 21, a Humanidade está diante de uma guerra silenciosa e sem bombas, porém muito perigosa, provocada por um vírus invisível, que ataca lentamente e age violentamente, hospedando-se num organismo, retardando um pouco para manifestar os sintomas de uma doença terrível; alguns contaminados revelam-se sintomáticos e outros assintomáticos. Ambas as situações indicam perigo e inspiram cuidados frente ao coronavírus.

Os coronavírus são vírus formados por Ácido Desoxirribonucleico (DNA) e Ácido Ribonucleico (RNA), apresentam uma estrutura envelopada, causam doença respiratória de gravidade variável, do resfriado comum à pneumonia fatal. Contudo, para os que deliram em subverter hegemonias, o vírus tem vida (QUAMMEN, 2020). "a semente de uma planta ainda dormente, sem sinais de metabolismo, é um ser vivo. Ela vibra, suspira e exala o desejo de viver, ainda que seja somente uma delicada promessa" (SATO et al. 2020, p. 4).

No território do Sisal, no qual estão inseridos o Campus XI da UNEB e o GEMA, grupo propulsor deste estudo, não está sendo diferente do restante do Brasil e da maior parte dos países do mundo, com o aumento de contaminados pelo vírus. Ante esse panorama, o não cumprimento de normas estabelecidas pela Organização Mundial de Saúde (OMS) e medidas de segurança para barrar o avanço da pandemia tem levado as pessoas ao precipício, uma vez que, como as estatísticas tem mostrado, não existe um grupo de risco, como se pensava: entre os inúmeros casos com vítimas fatais, estão muitos jovens.

A sociedade anseia por um serviço de saúde integral e de qualidade, como contrapartida ao que lhe falta naturalmente, já que todos dependem dos recursos naturais e do meio ambiente para viver com saúde. O meio ambiente tem dado respostas indesejadas para aqueles desavisados e destruidores da natureza; para os atentos, tais respostas são efeitos de causas bem conhecidas. 
Dessa forma, este estudo foi realizado com o intuito de estabelecer diálogo com os envolvidos sobre as questões socioambientais e a COVID-19, a partir da aplicação de uma enquete on-line. Sem o desejo de extenuar o tema, o presente trabalho dialoga com os participantes sobre o assunto que se tornou a "ordem do dia"; a correlação entre o coronavírus e o meio ambiente, com vistas a propor a esses participantes - e, posteriormente, chegando às esferas governamentais - ações, atividades de sensibilização e reflexões sobre o atendimento às medidas de prevenção e precaução. Oportunidade em que se utilizou da pesquisa bibliográfica, com o uso exclusivo de fontes selecionadas para este trabalho e também da participante, para auxiliar os envolvidos a identificar os seus problemas e a buscar as possíveis soluções.

Para tanto, apoiar-se-á na Educação Ambiental como um instrumento de estímulo, envolvimento e pertencimento, para a elaboração das ações de sensibilização, conscientização e das demais atividades que serão desenvolvidas no dia a dia dos cidadãos pós pandemia, conforme Sato (2004, p.17), "tal educação afirma valores e ações que contribuem para a transformação humana e social e para a preservação ecológica".

\section{Coronavírus e o meio ambiente: causa e consequência}

A ação humana vem afetando o meio ambiente ao longo dos anos e provocando diferentes causas, já que para atender às necessidades apresentadas na sociedade, o homem realiza diferentes ações as quais geram danos contínuos, na medida que se apropria do habitat e do nicho ecológico do ecossistema. Na dimensão em que o meio ambiente é ocupado pelo homem ocorre transformações inimagináveis, desmatamentos, queimadas, assoreamento de rios, introdução de vegetação não-nativa, extinção de espécies, dentre outros, causando desequilíbrios e a partir destes, consequências na natureza e no meio social. Nessa perspectiva, Alho (2012) afirma que:

Outros exemplos foram as recentes ocorrências de gripe aviária e gripe H1N1. Os hábitats naturais têm desaparecido ou ficado extremamente modificados, reduzidos e fragmentados, o que influi na relação estoque silvestre versus estoque doméstico versus homem, facultando 0 aparecimento de doenças. Enfim, a modificação de ecossistemas naturais torna o ambiente mais suscetível para o aparecimento de doenças ( $p$. 157).

A ocupação humana é responsável por parte dos surgimentos de patógenos ou suas mutações, e para que haja a sobrevivência do ecossistema e sua biodiversidade faz-se necessárias modificações. Alho (2012), alerta que o ecossistema sofre alterações e por consequência torna-se vetor de doenças. 
O site BBC News (2020) considera que muitas doenças provocadas por vírus vieram dos animais, e pesquisas apontam que os vírus são especialistas em sofrerem mutações e hospedarem-se em diferentes espécies. Nesse sentido, a COVID-19 é apresentada até o momento como uma mutação viral da família do coronavírus; acredita-se que esta mutação tenha ocorrido devido ao comércio de animais selvagens como cobra, morcego, pangolim, e outros, nos mercados chineses, conforme citado pelo EL País.

De acordo a Revista Superinteressante (2020):

Em 1988, a China estabeleceu uma lei de proteção da vida selvagem e que nunca foi atualizada desde então. No documento, são citadas 54 espécies permitidas para comercialização e consumo. Entre elas, têm texugos, crocodilos, hamsteres e até centopeias.

$\mathrm{Na}$ atual conjuntura, os efeitos da pandemia provocada pela COVID-19 estão cada dia mais perceptíveis no mundo. Conforme o site VG Resíduos (2020), situações inusitadas começaram a surgir em todo o planeta, a exemplo da redução de emissão de gases na atmosfera e também a diminuição dos níveis de Dióxido de Nitrogênio $\left(\mathrm{NO}_{2}\right)$ e Dióxido de Carbono $\left(\mathrm{CO}_{2}\right.$.). Nesse sentido, estudos da Universidade Federal de Juiz de Fora (2020), apontam que:

Imagens de satélite mostram que a pandemia do coronavírus está temporariamente diminuindo níveis de poluição do ar ao redor do mundo. Especialistas apontam a quarentena como o evento de maior escala já registrado em termos de redução de emissões industriais.

Com o silêncio das cidades, pode-se ouvir o canto dos pássaros; praias desertas deram lugar a reprodução e nascimento das tartarugas marinhas; na Itália, golfinhos foram filmados nadando no porto de Cagliari e os canais de Veneza deram um show ao exibir suas águas cristalinas. Para Martins et al. (2020), a diminuição da circulação dos animais humanos deu lugar para a espécie de animais não humanos circularem livremente, acasalarem-se e reproduzirem-se em seu habitat.

Tais afirmações chamam a atenção para uma realidade mais próxima, mais precisamente no território do Sisal, onde estão ocorrendo eventos parecidos: revoadas de garças, jaburus e de outras aves, já há muito não observadas, voltaram a ser notadas e vistas ao entardecer, durante o pôr do sol, fato esse que comunga com o estudo de Martins et al. (2020, p. 7), quando discorrem a presença de gralha-do-campo, lagarto, teiú, beija-flores e espécies 
de abelhas na área do parque do bondinho do pão-de-açúcar no Rio de Janeiro.

Isso prova de fato que a presença do animal humano interfere no ambiente, seja ele social ou natural. É importante salientar que isso não significa que as espécies tinham entrado em extinção ou desaparecido daqueles ambientes, e que somente agora estão reaparecendo, não! (Com o confinamento dos humanos, quer seja pelo distanciamento social, isolamento ou quarentena; terminologias que geram confusão no entendimento das pessoas, as quais a partir daqui serão referidas como 'confinamento', com as devidas definições nos resultados deste trabalho) elas se sentiram com liberdade para voltar a aparecer com mais frequência no seu habitat natural; no entanto, não devem se sentir seguras, pois as ameaças sempre existirão, e os inimigos estão por vir. Isso pode significar que a COVID-19 e sua relação com a questão socioambiental representa um importante alerta sobre 0 comportamento, atitude e ação do ser humano no ambiente que este compartilha com os outros animais.

\section{Instituições de ensino e o confinamento dos estudantes}

A pandemia desencadeada pelo coronavírus impactou diretamente as instituições de ensino, colocando-as diante de muitas questões complexas. Os impactos se dão a partir da ausência dos estudantes e professores no espaço físico, ensejando as aulas a distância, mesmo que essa prática tenha divergências de opiniões. Por isso a necessidade do questionamento: quais as estratégias a serem utilizadas para que a educação permaneça eficaz, com qualidade e, o principal, para que todos a alcancem nesse período marcado pelo o novo coronavírus? De forma que escolas, universidades, faculdades, e todas as instituições que atuam na área da educação para crianças, jovens, adultos e idosos busquem fomentar estratégias que garantam o bem-estar e a saúde.

Conforme Drucker (1954), estratégia é a análise sobre situações atuais, bem como as mudanças necessárias, visto que esta análise incorpora-se aos recursos disponíveis os quais precisam ser adquiridos. Deste modo, a estratégia é realizada com base na conjuntura presente, que busca traçar meios para alcançar resultados positivos em curto ou longo prazo, com vistas a que todos tenham ganhos favoráveis.

Nesta perspectiva, foram sugeridas algumas diretrizes a serem realizadas durante a pandemia com o objetivo de orientar estados, municípios, distrito federal e institutos de ensino sobre as práticas a serem adotadas:

Educação infantil - A orientação para creche e pré-escola é que os gestores busquem uma aproximação virtual dos professores com as famílias, de modo a estreitar vínculos e fazer sugestões de atividades às crianças e aos pais e responsáveis. 
Ensino fundamental anos iniciais - Sugere-se que as redes de ensino e escolas orientem as famílias com roteiros práticos e estruturados para acompanharem a resolução de atividades pelas crianças. No entanto, as soluções propostas pelas redes não devem pressupor que os "mediadores familiares" substituam a atividade do professor.

Ensino fundamental anos finais e ensino médio - $A$ supervisão de um adulto para realização de atividades pode ser feita por meio de orientações e acompanhamentos com o apoio de planejamentos, metas, horários de estudo presencial ou on-line, já que nesta etapa há mais autonomia por parte dos estudantes.

Ensino técnico - A ideia é ampliar a oferta de cursos presenciais em cursos de educação a distância (EaD) e criar condições para realização de atividades pedagógicas não presenciais de forma mais abrangente a cursos que ainda não se organizaram na modalidade a distância.

Ensino superior - O CNE sugere que, para a continuidade das atividades de ensino aprendizagem nesse nível de ensino, as instituições possam disponibilizar atividades não presenciais.

Educação de jovens e adultos (EJA) - Enquanto perdurar a situação de emergência sanitária, as medidas recomendadas para EJA devem considerar as condições de vida dos estudantes, para haver harmonia na rotina de estudos e de trabalho.

Educação Especial - As atividades pedagógicas não presenciais devem incluir os estudantes com deficiência, transtorno de espectro autista e altas habilidades/superdotação (BRASIL, 2020).

As Instituições de Ensino Superior (IES) tiveram até o presente estudo um total de 37.766 produtos fabricados e distribuídos para o combate ao coronavírus; desenvolveu 523 projetos educacionais e de apoio a pequenos empresários para combater à COVID-19, bem como arrecadações de alimentos para as famílias, que tiveram sua renda comprometida (SEMESP, 2020).

A UNEB, é uma das IES que vem contribuindo para combater o coronavírus. Em parceria com a Escola Bahiana de Medicina e Saúde Pública (EBMSP) e a Universidade Federal do Oeste da Bahia (UFOB), foi desenvolvido um projeto colaborativo intitulado "Face Shield for Life 3D", cujo objetivo é desenvolver máscaras de proteção individual para os profissionais de saúde, que estão atuando no combate à COVID-19, e, a partir disso, reduzir os riscos de exposição (UNIVERSIDADE DO ESTADO DA BAHIA, 2020).

O referido projeto, contribuiu para outras ações realizadas pela UNEB e outras IES públicas e privadas da Bahia, como a força-tarefa "Tele Coronavírus", que convoca estudantes do curso de medicina, entre o $9^{\circ}$ e $12^{\circ}$ 
semestre, para criar uma central de saúde, via Web-telefônica, tendo como objetivo atuar na triagem de casos suspeitos e orientar a população que residem na capital sobre o combate à doença (UNIVERSIDADE DO ESTADO DA BAHIA, 2020).

Vivendo, com isso, momentos de restrições, imposto pela pandemia, que tem exigido das pessoas e em especial dos estudantes, meios alternativos de desenvolver atividades acadêmicas. Durante o confinamento, a rotina dos estudantes está bem diferente, alguns tendo aula a distância, outros totalmente sem aulas. Para os que estão em ensino remoto em algumas instituições, tem sido grande o número de reclamações, pois nem todos os estudantes têm acesso à internet, dificultando assim, ou melhor, inexistindo a atividade on-line.

O MEC, publicou no DOU a Portaria no 374/2020 (BRASIL, 2020), na qual autoriza a antecipação de formatura dos estudantes de Medicina, Enfermagem, Farmácia e Fisioterapia, isso com vistas ao reforço no atendimento do sistema de saúde. Vale ressaltar que o Brasil não foi pioneiro nessa medida e sim a Itália, ante o quadro avassalador da COVID-19, implicando a perda de muitas vidas humanas no país europeu, onde os profissionais e os leitos hospitalares não davam conta da demanda no início da pandemia. O Brasil, no entanto, seguiu as recomendações do MEC, e o primeiro passo foi dado para a antecipação da colação de grau de estudantes, que já tenham cursado $75 \%$ do seu respectivo regime de internato para o curso de Medicina, e 20\% para os estágios específicos dos demais cursos. Importante salientar que esses estudantes, além de ter cumprindo tais créditos de estágio obrigatório, fizeram um cadastro, demonstrando interesse em estar apto para atuar na ação humanitária.

Vale destacar que o Conselho Estadual de Educação do Estado da Bahia (CEE / BA), em concordância com a Portaria 374/2020 do MEC, baixou a Resolução CEE/BA № 36/2020, que também autoriza a antecipação da colação de grau para os alunos do curso de Medicina, Enfermagem, Farmácia e Fisioterapia no sistema estadual de ensino, em caráter excepcional, como parte das ações de combate à pandemia do novo coronavírus (BAHIA, 2020).

Assim, como as instituições de ensino, vários estudantes, deram exemplos como os do curso de Sistema de Informação da Universidade Federal Rural de Pernambuco (UFRP), que criaram um aplicativo com potencial para ajudar no combate à propagação do vírus, possibilitando aos usuários, sua aplicação sem sair de casa, para evitar aglomerações em hospitais e centros de saúde; na UNEB, os estudantes do curso de Pedagogia do campus XI, através do Diretório Acadêmico, vem promovendo lives sobre violência doméstica em tempos de confinamento; O GEMA disponibilizou artigos e promoveu uma live com temática socioambiental; os estudantes do curso de Administração, também do campus XI, envolvidos, comprometidos e respeitosos ao confinamento, participam através da Realiza, Empresa Júnior, de lives com temas relacionados ao coronavírus e a gestão ambiental, junto a direção do Departamento; estudantes do campus I, também da UNEB, se 
mobilizam juntamente com professores na arrecadação de alimentos para serem doados às pessoas pobres, inclusive estudantes da própria instituição; estudantes do curso de Medicina da Universidade Estadual de Feira de Santana (UEFS), produz máscara caseira para doação.

Os estudantes de Medicina membros da Federação Internacional da Associação de Estudantes de Medicina (IFMSA) Brasil, da Universidade de Fortaleza e da Comunidade Carmens, criaram o espaço de acolhimento para compartilhar experiências e angústias, encontros virtuais elaborados por estudantes para contribuir na superação das dificuldades durante a pandemia. Todas essas são formas para que a pessoa se mantenha consciente, amenizando os efeitos negativos que o confinamento pode causar. $O$ estudante precisa se distrair, conversar, ouvir músicas, ler um bom livro. Como afirma a estudante Luiza Marques, do curso de medicina da Universidade de Fortaleza:

Estamos todos cheios de incertezas em relação ao cenário atual, mas, quando escutamos o outro, estamos também doando algo precioso, que é o tempo, dando o espaço e a importância para a história daquela pessoa que está sendo ouvida. E construímos a partir disso formas de entender melhor nosso papel individual dentro do coletivo (DIÁRIO DO NORDESTE, 2020, p. 2).

\section{Desafio cientista na busca da vacina e os profissionais de saúde}

Sem dúvida, a busca incessante para frear e encontrar a cura para a COVID-19 é notória e desafiadora para cientistas e pesquisadores em cinco dos continentes. Isso, "desde que os chineses divulgaram, pioneiramente, 0 sequenciamento genético do novo vírus, em janeiro de 2020, início de uma corrida entre empresas e institutos de pesquisa de vários países para o desenvolvimento da vacina" (NEGRI et al. 2020).

Vale ressaltar que "os coronavírus humanos (CoVh) são responsáveis por ocasionar doenças respiratórias e entéricas, sendo associados às infecções agudas e graves do trato respiratório" (AKIM et al. 2014), sendo necessário redobrar os cuidados com as Infecções Respiratórias Agudas (IRA), pois além das causas de morbidade, ocasionam altas taxas de mortalidade em todo o planeta. Conforme Akim et al. (2014), "os vírus são considerados os agentes etiológicos predominantes em IRA, sejam como patógenos principais, ou predispostos indivíduos a infecções bacterianas secundárias".

De acordo a Negri et al. (2020), diversos países do mundo têm procurado coordenar suas iniciativas de pesquisa internamente e articular os esforços àqueles identificados pela OMS. O Brasil, através da Fiocruz, do Instituto Butantan e de algumas Universidades, a exemplo da Universidade Federal de São Paulo (UNIFESP), por meio de seu centro de referência e laboratórios. 
A cientista Daniela Ferreira, "ressalta que a produção de uma vacina é um processo demorado, que pode durar mais de uma década, mas que a colaboração entre cientistas do mundo todo em busca de uma forma de vacinação é um movimento "extraordinário" (MANZANO, 2020). Os estudos avançam na busca pela vacina e, de acordo a Agência Nacional de vigilância Sanitária (ANVISA), recentemente "foram feitos estudos iniciais em animais $e$ em humanos para avaliar a segurança da vacina que esta sendo desenvolvida pela Universidade de Oxford na Inglaterra" (CARDIM, 2020).

A COVID-19, como as outras epidemias recentes, confronta a utopia sanitária de fronteiras rígidas entre espécies, tanto no domínio espacial, quanto epistemológico e cultural. Os persistentes chamados trazidos pela pandemia por ações coordenadas de abrangência global, preveem também a conjugação de campos do saber radicados no estabelecimento dessas fronteiras. As "espécies companheiras" para Haraway (2008), não são apenas os animais domésticos, os ameaçados de desaparecimento, mas incluem os fungos, as bactérias e, neste caso, os vírus, "criaturas" que estão diante do que se entende por ser vivo.

O que dizer de pessoas, que escolheram ser profissionais da saúde? Que lidam diariamente com alegrias e tristezas, delas mesmas e dos outros, especialmente de seus pacientes, sobretudo neste momento de crise sanitária, imposta pelo novo coronavírus, senão a reafirmação da premissa de que o profissional de saúde é um bem público! Sim, mas esse bem público é um ser humano, e como tal, precisa estar preparado para exercer uma função tão essencial. Antes de qualquer coisa, o profissional de saúde precisa ter vocação para atuar na área, e ter determinação para exercer o seu ofício como uma missão especial, já que terá que lidar com diversas situações, muito difíceis, como esta de enfrentamento do coronavírus, que está associado às infecções agudas graves do trato respiratório e entérico. Como descreve Machado (2020):

Sabemos, pois, que o enfrentamento da pandemia da COVID19 , em nosso país tem sido possível por conta exatamente do SUS e seus trabalhadores, já que são eles os profissionais que estão todos os dias e horas dando o seu esforço e assistência direta à população nos hospitais e ambulatórios, na ciência, tecnologia produzindo e disponibilizando saberes, conhecimentos, enfim, prestando serviços.

Esses profissionais, conhecidos mundialmente, como os que salvam "vidas", abdicam de suas famílias, dos seus momentos de lazer e entretenimento, sendo, às vezes, obrigados a triplicar a sua carga horária de trabalho em jornadas de puro risco. Riscos estes, não somente pelo o atendimento aos acometidos do vírus ou outras doenças contagiosas, mas, na maioria das vezes, pela ausência de EPIs e do básico necessário nas unidades de saúde para o socorro às vítimas. 
Em meio a esse momento de incerteza, os trabalhadores em geral, incluindo os da saúde, têm sido impactados com as medidas provisórias que flexibilizam as condições de trabalho. Entre elas, a Medida Provisória 927/2020, flexibiliza as horas extras e a suspensão de exigências administrativas em segurança e saúde no trabalho, e a MP 936/2020, que prevê a possibilidade de redução de salário por meio de uma negociação individual entre o trabalhador e empregador (FIOCRUZ, 2020).

Silva et al. (2015) afirmam que, pior que a pressão que os trabalhadores da área de saúde sofrem no momento de atender e salvar vidas, são os fatores que compõem os aspectos psicossociais, que mais desencadeiam o estresse no ambiente laboral. São eles: aspectos da organização, administração, sistema de trabalho e das relações interpessoais.

\section{Prevenção e esperança, o último alento}

São três as estratégias para se combater uma pandemia: contenção, mitigação e supressão. As medidas de contenção acontecem nas primeiras fases do surto e têm por objetivo localizar e isolar os casos de infecção, além de vacinação, para impedir que a doença se propague. Quando não é possível conter a doença, as medidas passam a estar focadas em atrasar e mitigar os seus efeitos na sociedade e nos sistemas de saúde. Já as ações de supressão requerem que sejam tomadas medidas mais extremas para reverter a pandemia ao diminuir o número reprodutivo para menos de 1 (WIKIPÉDIA, 2020).

Brasil (2020) recomenda intervenções não farmacológicas de medidas básicas na prevenção da COVID-19, sendo essas, precauções de higiene como: o simples fato de lavar bem as mãos com água e sabão ou higienizador à base de álcool, fazendo os movimentos de friç̧ão nas palmas, dorsos, dedos, unhas, punhos etc.; para isso, são necessários mais ou menos 20 a 30 segundos de lavagem, em um processo que independe do tipo de sabão e, de preferência, utilizar toalhas de papel para secá-las. Essas medidas são recomendadas ao lado de orientações para não se compartilhar objetos pessoais e cobrir o nariz e a boca ao espirrar ou tossir, além de manter o ambiente ventilado, por exemplo.

Para a limpeza doméstica, recomenda-se o uso os produtos usuais, dando preferência aos detergentes e desinfetantes a base de cloro, misturados com água para desinfetar superfícies, importando saber que o tempo de vida do vírus em algumas superfícies é a seguinte: papelão, um dia; aço inoxidável e plástico, três dias; vidro, quatro dias; cobre, quatro horas; alumínio, oito horas; tecidos, de 72 a 96 horas e poeira, de 40 minutos a $2 \mathrm{~h} 30$ (SANARMED, 2020).

O que ainda resta à humanidade neste tempo de pandemia? Sem sombra de dúvidas, o que não se pode é perder a esperança por dias melhores, esta sempre serviu de alento para muita gente, uma vez que mesmo 
em meio a um período de escuridão, é possível tecer reflexões com o intuito de tirar proveito de todas as situações, inclusive as mais sofridas e dolorosas. É por meio da esperança que o homem conquista a felicidade, que para Cortella et al. (2019, p.47):

É impossível ser feliz se você não experimentar a misericórdia, se você não experimentar a possibilidade de perdoar pessoas, e se você não experimentar a possibilidade de ser perdoado por pessoas. Portanto, a felicidade não é possível se você não tiver consciência de que tem culpa de muita coisa e de que faz muita coisa errada.

\section{Metodologia}

Considerando a complexidade inerente ao coronavírus e sua relação com as questões socioambientais, buscou apoio na pesquisa dos tipos bibliográfica e participante. A bibliográfica é "elaborada com base em material já publicado, tradicionalmente, esta modalidade de pesquisa inclui material impresso, como livros, revistas, jornais, dissertações, teses e anais de eventos científicos" (GIL, 2010, p. 29). E se tratando de algo novo e desafiador, e ainda com pouca publicação, os pesquisadores fizeram leituras de livros, artigos, periódicos, boletins, folhetos, jornais, sites etc. Já a pesquisa participante "trata-se, portanto de um modelo de pesquisa que difere das tradicionais porque a população não é considerada passiva e seu planejamento e condução não ficam a cargo de pesquisadores profissionais" (GIL, 2010, p. 43). Estes participam, se envolvem, opinam, sugerem, deixam seus registros e querem respostas. Importante salientar que se trata de um estudo de abordagem qualitativa, no qual, segundo Alves (2007, p. 58), "o pesquisador procura captar a situação ou fenômeno em toda a sua extensão". A coleta de dados foi iniciada com a busca nos documentos impressos, já mencionados e nas 40 enquetes aplicadas, com vistas a dialogar com os participantes sobre o vírus e as questões socioambientais. O tratamento dos dados da pesquisa foi realizado a partir de sistematização simples com o uso do Programa Microsoft Office (Word, versão 2016). O estudo norteou-se nas seguintes etapas procedimentais:

Etapa 1: Informação e sensibilização - aconteceu na segunda quinzena de março de 2020, no contato on-line com os membros do GEMA, logo após os pesquisadores chegarem de uma viagem de estudo, quando foram surpreendidos com uma Portaria da Reitoria suspendendo todas as atividades presenciais em todos os campi da UNEB, visando evitar a propagação do coronavírus. Tal decisão provocou nos pesquisadores sensações de espanto, medo, insegurança, pânico etc. E a partir daí começaram as inquietações de todo o seguimento universitário (como se vai concluir o semestre?). Isso foi contornado, e o semestre em andamento foi concluído. Adentrou-se na primeira quinzena de abril com uma nova rotina com envio on-line de poesias, músicas, mensagens, tudo com a intenção de se buscar a paz, a união, a integração, uma 
espécie de conforto diante do novo. E logo surgem as lives, com o propósito de maior discussão sobre a temática. E por solicitação do GEMA, da Empresa Júnior do curso de Administração, dos colegiados dos cursos, direção, de professores e estudantes foi recomenda diversas leituras, filmes, séries, com vistas a não se perder o foco, o ponto de equilíbrio, a harmonia, garantindo assim o contato, estimulando o relaxamento, passando segurança.

Etapa 2: Identificação e desenvolvimento - mediante leitura específica de livros, artigos, folhetos, boletins, jornais, consultas a sites etc., relacionados ao coronavírus e ao meio ambiente, durante a segunda quinzena de abril de 2020;

Etapa 3: Construção - no final da segunda quinzena de abril de 2020, elaborou-se a enquete que foi aplicada a dez estudantes dos cursos de Administração, Geografia e Pedagogia e mais dez professores, trabalhando-se ao todo com uma população amostral de quarenta pessoas;

Etapa 4: Contato prévio - envio da enquete de forma on-line para os que dispuseram a participar do estudo; isso se deu no início de maio de 2020;

Etapa 5: Devolutiva - na segunda quinzena de maio de 2020, recebimento da enquete para processamento;

Etapa 6: Execução - durante a segunda quinzena de maio de 2020 e a primeira quinzena de junho de 2020 , houve a leitura e processamento da enquete a partir da análise dos registros de cada participante, a qual está descrita nos resultados deste estudo; tais resultados, mais a consulta bibliográfica e as lives permitiram a construção do presente artigo;

Etapa 7: Retorno - divulgação dos resultados para os participantes e para as comunidades universitária e geral;

Etapa 8: Socialização - base fundamental e inicial para atuação e intervenção do GEMA junto à escola e à comunidade, quando as atividades presenciais retornarem. Nesse momento realizaremos, rodas de conversa, palestras, minicursos, oficinas, teatro, programas de tv e rádio, contação de histórias, vivências, jogos ecológicos educativos, gincana ambiental, construção de mapas conceituais, tertúlia dialógica, paródia, literatura de cordel, painéis, caça-palavras. Distribuição de cartilhas e folhetos educativos que serão construídos com a temática: educação, vírus e saúde socioambiental. Vivenciar e extrapolar o lúdico, extravasando a Educação Ambiental no viés interdisciplinar. 


\section{Resultados}

É notório que o modelo capitalista adotado atualmente, põe em risco o meio ambiente, colocando-o em degradação, quando incentiva um consumo permanente e equivocado, passando a impressão de que a natureza é uma fonte inesgotável de recursos.

Como a pandemia está relacionada fortemente a um processo de educação e saúde socioambiental, após a realização de muitas leituras, os pesquisadores descobriram que, além dos seis coronavírus humanos (HCoVs) já existentes, os HCoV-229E, HCoV-OC43, HCoV-NL63, HCoV-HKU1, SARSCOV, que causam síndrome respiratória aguda grave, e o MERS-COV, que causa a síndrome respiratória do Oriente Médio, surge um novo coronavírus identificado. No início, o novo vírus foi nomeado como 2019-nCoV, mas no dia 11 de fevereiro de 2020, foi renomeado de SARS-CoV-2, sendo o causador da doença COVID-19 (OPAS/BRASIL, 2020).

Um vírus avassalador, que num curto espaço de tempo atravessou fronteiras e ganhou o mundo, atingindo 188 países em cinco continentes. Essa tragédia não isentou o Brasil, que hoje está passando por uma situação grave e muito preocupante, na liderança do segundo lugar mundial em casos do coronavírus, registrando números recordes em várias cidades brasileiras.

A exemplo de outros países gravemente afetados, o Brasil vai sofrer muitas perdas, por mais que tome medidas para combate ao coronavírus, por causa da ausência de políticas públicas referentes a saneamento básico e preservação e conservação de suas reservas e recursos naturais em geral, representando uma negligência gritante. $E$ com isso, conforme já declarado por vários estudiosos, as espécies não humanas hospedeiras de tais vírus, têm perdido seu habitat natural pela invasão humana gananciosa nos mais variados aspectos; essas espécies buscam refúgios mais próximo dos humanos, estabelecendo assim possível contato destes com o vírus.

A ausência e/ou o não cumprimento da legislação ambiental, as permissões governamentais de comercialização de animais silvestres e outras espécies exóticas para fins decorativos e alimentar sem nenhuma fiscalização, controle, inspeção pela vigilância sanitária dessas práticas milenares em todo o mundo, possibilitam que mercados e feiras livres mundo a fora comercializem esse tipo de animal, incentivando assim o tráfico ilegal dessas espécies, inclusive da fauna protegida ou já ameaçada de extinção (WIKIPÉDIA, 2020).

Durante a realização da pesquisa, o novo provocou os pesquisadores, levando-os ao envolvimento com outras pessoas, a exemplo da enquete aplicada, cujas análises foram iniciadas pelas dos professores, quando foi perguntado a eles como se sentem diante da pandemia do coronavírus? Quatro deles disseram se sentir inseguros; dois sentem medo; dois, pânico; um, em risco e para surpresa dos pesquisadores, um dos professores sente-se imune. Isso é um tanto preocupante, pois, para o professor de Medicina, Paul Hunter, da Universidade de East Anglia, na Inglaterra, "a questão não é se 
você fica imune, é por quanto tempo você está imune" (BBC NEWS BRASIL, 2020).

Tratando-se de uma realidade pandêmica como a que a Humanidade está vivendo, quem é ou são os culpados? Para sete professores, ninguém é culpado; dois acham que é o presidente; um entrevistado não respondeu. Apesar das farpas trocadas entre as duas maiores economias mundiais (China e EUA), não existe um culpado por propagar ou produzir o coronavírus, como já divulgado exaustivamente pela mídia, que dá conta da origem e meios de transmissão do vírus. Entretanto, há controvérsias acerca da data em que ocorreu o primeiro caso da doença, que naquele momento fora tratada como simples pneumonia, sendo identificada posteriormente como SARS-CoV-2. Segundo o Jornal "South China Morning Post" de Hong Kong, o primeiro caso ocorreu em 17 de novembro de 2019, vitimando uma pessoa de 55 anos da província de Hubei em Wuhan, mas as autoridades chinesas somente alertaram a OMS em 31 de dezembro daquele ano, sobre casos de pneumonia na mesma cidade (CURY, 2020).

Longe das controvérsias, pesquisas avançam, e um estudo do Instituto Nacional de Saúde Italiano, concluiu que nas águas residuais de Bolonha, Milão e Turim continha a presença do novo coronavírus desde 18 de dezembro de 2019 (PORTAL G1, 2020).

Ao serem indagados sobre as medidas de prevenção para evitar ser contaminados, seis professores optaram pelo distanciamento social; quatro opinaram pelo isolamento. É importante que se entenda a diferença entre distanciamento social, isolamento e quarentena. Isolamento é para a pessoa que testou positivo para a COVID-19 e deve se isolar em domicílio ou em ambiente hospitalar, para evitar a propagação do vírus enquanto que distanciamento social é quando a pessoa está fazendo a sua parte para reduzir o risco de transmissão do vírus, mantendo-se distante das demais, já a quarentena, refere-se a pessoa que esteve em contato com alguém contaminado e está aguardando para ver se tem sintomas, ou não. (OPAS/BRASIL, 2020).

Sobre a afirmação "a degradação ambiental afeta e causa o desequilíbrio de várias formas de vida e, consequentemente, produz riscos e agravos à saúde coletiva", os dez professores a consideram correta. Essa unanimidade dos professores comunga com aquilo que cientistas, estudiosos e pesquisadores do mundo inteiro relatam sobre a devastação do ambiente no decorrer de muitos anos, por meio de práticas destruidoras como desmatamentos, queimadas, e o costume milenar de aplicar pesticidas, germicidas, detergentes, como o Dicloro-Difenil-Tricloroetano, popularmente conhecido como DDT, nos cultivos agrícolas com o objetivo de eliminar os insetos/pragas, prejudicando flora, fauna, solo, recursos hídricos, além dos humanos, provocando várias doenças, como mostram as pesquisas do Dr. William Deichmann, da Universidade de Miami: 
Exames patológicos realizados por esse cientista em diversos indivíduos portadores de leucemia e câncer no fígado constataram a existência de duas a três vezes mais resíduos de DDT, Aldrin, Dieldrin e produtos afins nesses doentes do que os exames realizados em vítimas de outras moléstias (CARVALHO, 1989, p. 25).

Sabe-se que a utilização de DDT causa uma série de efeitos colaterais, provocando o envenenamento e morte não somente dos insetos, mas também do solo, dos peixes, dos rios, dos pássaros e do próprio homem. Os livros clássicos sobre o meio ambiente, Primavera Silenciosa de Rachel Carson, lançado em 1962, alerta sobre o perigo do DDT, já O Futuro Roubado de Theo Colborn, Dianne Dumanoski e John Peterson Myers, lançado em 1996, adverte sobre o uso indiscriminado de agrotóxicos e outros agentes químicos.

Ao serem interpelados sobre a asseveração de que "os vírus são capazes de percorrer distâncias em quilômetros, incalculáveis", sete professores foram taxativos ao afirmarem que é certo; três consideram errada. Sabe-se sim, que os vírus ultrapassam até fronteiras, quando, em viagem, uma pessoa contaminada transmite-o a outra. Logo, o contágio se dá de pessoa para pessoa, ou através do contato com algum animal hospedeiro, conforme aponta Tesini (2020), quando diz que "os primeiros casos da COVID-19 foram ligados a um mercado de animais vivos em Wuhan, na China, sugerindo que o vírus tenha sido inicialmente transmitido de animais para os humanos".

Como já dito, este estudo foi desenvolvido com professores e estudantes do campus XI da UNEB, abrangendo três cursos de graduação, sendo que a categoria dos estudantes foi analisada por curso, conforme Quadro1.

Quadro 1: Respostas dos estudantes à enquete aplicada durante o estudo.

\begin{tabular}{|c|c|c|c|}
\hline ABORDAGEM & ADMINISTRAÇÃO & GEOGRAFIA & PEDAGOGIA \\
\hline $\begin{array}{l}\text { Como se sentem diante a pandemia do } \\
\text { coronavírus? }\end{array}$ & $\begin{array}{l}5 \text { medo } \\
3 \text { risco } \\
2 \text { inseguros }\end{array}$ & $\begin{array}{l}8 \text { inseguros } \\
1 \text { medo } \\
1 \text { risco }\end{array}$ & $\begin{array}{l}5 \text { inseguros } \\
3 \text { medo } \\
2 \text { risco }\end{array}$ \\
\hline $\begin{array}{l}\text { Na realidade pandêmica a qual está se } \\
\text { vivendo, quem é ou quem são os } \\
\text { culpados? }\end{array}$ & $\begin{array}{l}4 \text { Presidente } \\
4 \text { ninguém } \\
2 \text { OMS }\end{array}$ & $\begin{array}{l}4 \text { Presidente } \\
4 \text { OMS } \\
1 \text { ninguém } \\
1 \text { não respondeu }\end{array}$ & $\begin{array}{l}5 \text { ninguém } \\
2 \text { OMS } \\
1 \text { Presidente } \\
1 \text { Governo } \\
1 \text { não respondeu }\end{array}$ \\
\hline $\begin{array}{l}\text { Medidas de prevenção para evitar ser } \\
\text { contaminados: }\end{array}$ & $\begin{array}{l}5 \text { distanciamento } \\
3 \text { isolamento } \\
2 \text { quarentena }\end{array}$ & $\begin{array}{l}5 \text { distanciamento } \\
4 \text { isolamento } \\
1 \text { quarentena }\end{array}$ & $\begin{array}{l}5 \text { distanciamento } \\
4 \text { isolamento } \\
1 \text { aglomeração }\end{array}$ \\
\hline $\begin{array}{l}\text { "A degradação ambiental afeta e causa } \\
\text { o desequilíbrio de várias formas de } \\
\text { vida e, consequentemente, produz } \\
\text { riscos e agravos à saúde": }\end{array}$ & $\begin{array}{l}9 \text { correta } \\
1 \text { errada }\end{array}$ & $\begin{array}{l}7 \text { correta } \\
2 \text { duvidosa } \\
1 \text { errada }\end{array}$ & 10 correta \\
\hline $\begin{array}{l}\text { "Os vírus são capazes de percorrer } \\
\text { distâncias em quilômetros } \\
\text { incalculáveis": }\end{array}$ & $\begin{array}{l}5 \text { certo } \\
5 \text { errado }\end{array}$ & $\begin{array}{l}6 \text { errado } \\
4 \text { certo }\end{array}$ & $\begin{array}{l}6 \text { certo } \\
4 \text { errado }\end{array}$ \\
\hline
\end{tabular}

Fonte: autoria própria. 
A opção por apresentar a análise das respostas dos estudantes em separado da análises dos professores se deu para evitar repetição de alguns comentários, e também porque dessa forma, a interpretação flui melhor, já que se trata da análise de uma enquete de cinco perguntas fechadas.

A pergunta sobre as sugestões dos professores e dos estudantes divergem, mas também convergem, de acordo com os aspectos: político, social, cultural, econômico, saúde, educação, religião etc. Mas o que chamou muita atenção foi a revelação de sentimentos, convicções e virtude, como: fé, gratidão, perdão, culpa, espiritualidade, religião, conscientização, paciência, afeto, calma, demostrando preocupação e responsabilidade (Quadro 2).

Quadro 2 - Sugestões dos professores e dos estudantes participantes do estudo.

\begin{tabular}{|c|c|c|}
\hline CATEGORIA & PARTICIPANTE 1 & PARTICIPANTE 2 \\
\hline $\begin{array}{l}\text { ESTUDANTE DE } \\
\text { ADMINISTRAÇÃO }\end{array}$ & $\begin{array}{l}\text { "Acredito que pouca coisa mudará } \\
\text { depois da pandemia no sentido do } \\
\text { nosso comportamento em relação } \\
\text { às pessoas, crenças, ideologias; } \\
\text { somos seres incoerentes e nem a } \\
\text { morte em massa, como estamos } \\
\text { vendo, é capaz de modificar } \\
\text { sobretudo o pensamento de } \\
\text { bilhões de pessoas". }\end{array}$ & $\begin{array}{l}\text { "A melhor alternativa é o } \\
\text { distanciamento social e trabalhar a } \\
\text { humanização em todos. Ser } \\
\text { solidários uns com os outros. É } \\
\text { importante que haja incentivo e } \\
\text { condições financeiras, econômicas, } \\
\text { sociais e psicológicas por parte dos } \\
\text { governantes para a pesquisa, } \\
\text { principalmente para as } \\
\text { universidades brasileiras". }\end{array}$ \\
\hline $\begin{array}{c}\text { ESTUDANTE DE } \\
\text { GEOGRAFIA }\end{array}$ & $\begin{array}{l}\text { "O mundo precisa de mais empatia } \\
\text { com o próximo, pois se todos } \\
\text { tivessem esse pensamento, esse } \\
\text { vírus não teria se propagado } \\
\text { assim; muitos, mesmo sabendo do } \\
\text { risco, continuaram a viajar, a sair, } \\
\text { prejudicando a si e ao próximo". }\end{array}$ & $\begin{array}{l}\text { "Permanecer com o isolamento } \\
\text { social, maiores investimentos nos } \\
\text { sistemas de saúde, ampliação dos } \\
\text { leitos de UTI, voltar a olhar para } \\
\text { outros problemas epidemiológicos } \\
\text { que o Brasil enfrenta, como a } \\
\text { dengue e o sarampo". }\end{array}$ \\
\hline $\begin{array}{l}\text { ESTUDANTE DE } \\
\text { PEDAGOGIA }\end{array}$ & $\begin{array}{l}\text { "Cumprir as medidas de proteção, } \\
\text { ter fé em Deus e procurar ficar } \\
\text { tranquilo, ter os cuidados } \\
\text { necessários, ter uma visão crítica } \\
\text { do que a OMS está nos } \\
\text { aconselhando e nós é quem } \\
\text { sabemos até onde ir e como ir". }\end{array}$ & $\begin{array}{l}\text { "Que a polícia atue rigorosamente } \\
\text { nas questões dos bares que } \\
\text { desobedecem aos decretos, no } \\
\text { fechamento das fronteiras e em toda } \\
\text { a cidade garantindo o cumprimento } \\
\text { dos cuidados necessários para o } \\
\text { enfrentamento da COVID-19 pelos } \\
\text { cidadãos". }\end{array}$ \\
\hline PROFESSOR $(\mathrm{A})$ & $\begin{array}{l}\text { "Seguir as normas e orientações } \\
\text { dos especialistas da área, criar } \\
\text { estratégias diversas para manter o } \\
\text { equilíbrio mental e corporal". }\end{array}$ & $\begin{array}{l}\text { "Buscar trabalhar a mente. Para } \\
\text { tanto, ler, ouvir boa música, orar, } \\
\text { assistir bons filmes, de preferência } \\
\text { comédias e/ou de baixo impacto } \\
\text { emocional, dialogar: pelo telefone, } \\
\text { redes sociais, via whatsapp, com } \\
\text { pessoas agradáveis". }\end{array}$ \\
\hline
\end{tabular}

Fonte: autoria própria. 
Parafraseando Martins et al. (2020, p. 11), "como desdobramento as reflexões esboçadas aqui (...)", os membros do GEMA assumiram um compromisso quando estabeleceram parceria entre universidade, escola e comunidade, intervindo junto a professores e estudantes em suas práticas pedagógicas no sentido de trabalhar conteúdos complementares numa visão interdisciplinar, cuja atuação foi previamente, diagnosticada e planejada.

\section{Considerações finais}

A COVID-19 coloca em risco a sobrevivência da Humanidade e a estabilidade econômica das nações, principalmente da população vulnerável e dos tão conhecidos países do terceiro mundo, que já vivem o dia a dia fora da "normalidade", em meio a tanta precariedade imposta pela desigualdade mundial dos países ricos sobre os países pobres. Vive-se no limite, isso porque os governantes, não querem enxergar 0 que isso significa e resultará em consequências desastrosas.

Com relação aos questionamentos da enquete, chamou muito a atenção dos pesquisadores os saberes e conhecimentos dos participantes sobre 0 coronavírus. Acredita-se que isso se deva à experiência dos que já passaram com outros vírus, desastres e impactos socioambientais, bem como às leituras que muitos tem feito sobre a COVID-19, em momentos de confinamento.

As disciplinas Educação Ambiental, Educação e Saúde, Gestão Ambiental e Análise Ambiental, que compõem um bloco que pode ser denominado Educação e Saúde Socioambiental, ofertadas nos cursos da UNEB, campus $\mathrm{XI}$, devem se alinhar numa discussão no sentido de se atentar a esses chamados silenciosos que ocorre no dia a dia nas comunidades, tão graves como as pandemias de ordem mundial.

Espera-se que quando tudo isso passar, se possa fazer diferente e não ser tão pessimista como o/a estudante 1 do curso de Administração que diz “(...) pouca coisa mudará depois da pandemia, somos seres incoerentes e nem a morte em massa como estamos vendo é capaz de modificar sobretudo o pensamento de bilhões de pessoas". Mas como bem dizem Sato et al. (2020, p. 10), "é muito pouco provável, assim, que a COVID-19 seja tomada como aprendizagem. A mudança do mundo ainda dependerá de grandes esforços daqueles que buscam uma civilização mais ética".

\section{Referências}

ALHO, C.J.R. Importância da biodiversidade para a saúde humana: uma perspectiva ecológica. Rev Estudos Avançados. v.26 ํ․74. São Paulo, 2012. Disponível em: https://doi.org/10.1590/S0103-40142012000100011>. Acesso em:12 de maio de 2020.

ALVES, M. Como escrever teses e monografia: um roteiro passo a passo. $2^{\underline{a}}$ ed. Rio de Janeiro: Elsevier, 2007. 
AKIM, F. S. N.; SOUSA, R. C. M.; SANTOS, M. C. dos; BARBAGELATA, L.S.; COSTA JÚNIOR, E.; LIMA, D. F.; SOUSA, E. M. A. de; MELLO, W. A. de. Primeira detecção de coronavírus humano associado à infecção respiratória aguda na região norte do Brasil. Rev Pan-Amazônica de Saúde, Ananindeua - PA, v. 5 no 2, p. 10-12, 2014.

BAHIA. Secretaria da Educação do Estado da Bahia. CEE. Resolução № 36/2020. Salvador, 2020.

BBC NEWS BRASIL. Imunidade e coronavírus: é possível pegar COVID-19 mais de uma vez? Esta e outras questões ainda sem resposta. Disponível em: bbc.com/portuguese/internacional-52686096. Acesso em: 10 maio 2020. BRASIL. Ministério da Educação. Conselho Nacional de Educação. CNE aprova diretrizes para escolas durante a pandemia. Disponível em: http://portal.mec.gov.br/component/content/article/12-noticias/acoesprogramas-e-projetos-637152388/89051-cne-aprova-diretrizes-para-escolasdurante-a-pandemia?ltemid=164. Acesso em: 13 de maio de 2020.

BRASIL. Ministério da Saúde. Orientações da OMS para prevenção da COVID-19. Disponível em: <https://sbpt.org.br/portal/covid-19-oms/>. Acesso em: 6 de maio de 2020.

BRASIL. Ministério da Educação. Portaria no 374, de 3 de abril de 2020. DOU: 6 de abr. de 2020. Brasília: MEC, 2020.

CARDIM, M. E. Correio Braziliense. Brasil vai testar vacina contra COVID-19 desenvolvida no reino Unido. Disponível em: $<$ https://www.correiobraziliense.com.br/app/noticia/brasil/2020/06/03/brasil-vaitestar-vacina-contra-covid-19>. Acesso em: 4 de jun. de 2020.

CARVALHO, C. G. de. A natureza pede socorro. $2^{\underline{a}}$ ed. Cuiabá: Verde pantanal, 1989.

CORONAVÍRUS: por que os humanos estão pegando mais doenças transmitidas por animais? BBC News. Disponível em: https://www.bbc.com/portuguese/internacional-51325467. Acesso em: 12 de maio de 2020.

CORTELLA, M. S.; KARNAL, L.; PONDÉ, L. F. Felicidade: modos de usar. São Paulo: Planeta do Brasil, 2019.

CURY, M. E. Novo coronavírus pode ter surgido antes de dezembro. Disponível em: <https://exame.com/ciência/novo-coronavirus-pode-ter-surgidoantes-de-dezembro>. Acesso em: 25 de maio de 2020.

DRUCKER, P. The practice of management. New York: Harper e Brothers, 1954.

FIOCRUZ. A saúde dos que estão na linha de frente. Disponível em: https://portal.fiocruz.br/noticia/covid-19-saude-dos-que-estao-na-linha-de-frente. Acesso em: 8 de maio de 2020.

GIL, A. C. Como elaborar projeto de pesquisa. 5a ed. São Paulo: Atlas, 2010. 
HARAWAY, D. When species meet. Saint Paul: University of Minnesota Press, 2008.

IMUNIDADE e coronavírus: é possível pegar covid-19 mais de uma vez? Esta e outras questões ainda sem resposta. 2020. BBC NEWS BRASIL. Disponível em: bbc.com/portuguese/internacional-52686096. Acesso em: 10 mai. 2020.

MACHADO, M. H. Profissionais de saúde em tempos de COVID-19.

Disponível em:http://www.ensp.fiocruz.br/portalensp/informe/site/materia/detalhe/48453. Acesso em: 8 de maio de 2020.

MANZANO, F. Brasileira que coordena testes com vacina para COVID-19 na Inglaterra explica dilema da prova de eficácia. Disponível: https://g1.globo.com/bemestar/vacina/noticia/2020/05/28/brasileira-quecoordena-testes-com-vacina-para-covid-19-na-inglaterra-explica-dilema-daprova-de-eficacia.ghtml. Acesso em: 29 de maio de 2020.

MARTINS, E. C. D.; CRUZ, E. P.; SANTOS, S. F. Imaginações multiéspecies sobre o novo coronavírus. Rev Estudos Libertários (REL). Rio de janeiro: UFRJ, v. 2,p. 2-4, № 3, Edição Especial N 1.

NEGRI, F. de; ZUCOLOTO, G.; MIRANDA, P.; KOELLER, P. Ciência e tecnologia frente à pandemia. Ipea, 2020. Disponível em: $<$ <ttps://ipea.gov.br/cts/pt/central-de-conteudo/artigos/artigos/182-corona>.

Acesso em: 5 de maio de 2020.

NOVO coronavírus já estava presente em esgoto na Itália dois meses antes de registro oficial. PORTAL G1 de 19 de junho de 2020. Disponível em: https://g1.globo.com/jornal-nacional/noticia/2020/06/19/novo-coronavirus-jaestava-presente-em-esgoto-na-italia-dois-meses-antes-de-registro-oficial.ghtml. Acesso em: 22 de jun. de 2020.

O QUE são os mercados chineses de animais silvestres? Rev Superinteressante. Disponível em: https://super.abril.com.br/sociedade/o-quesao-os-mercados-chineses-de-animais-silvestres/ Acesso em: 1 de maio de 2020.

OPAS/BRASIL. Folha Informativa - COVID-19 (doença causada pelo novo coronavírus). 29 de junho de 2020. Disponível em: https://www.paho.org/bra/index.php?option=com content\&view=article\&id=610 1:covid19\&ltemid=875. Acesso em: 29 de jun. de 2020.

PANDEMIA de COVID-19. WIKIPÉDIA. Disponível em: https://pt.wikipedia.or./wiki/pandemia de covid-19. Acesso em: 22 de jun. de 2020.

PROJETO oferta encontros virtuais para quem precisa conversar. DIÁRIO DO NORDESTE. 1 de maio de 2020 Disponível em: https://g1.globo.com/ce/ceara/noticia/2020/05/01/estudantes-de-medicina-doceara-realizam-encontros-isolamento.ghtml. Acesso em: 3 de maio de 2020.

QUAIS possíveis efeitos do coronavírus sobre o meio ambiente? VG Resíduos. Disponível em: https://www.vgresiduos.com.br/blog/quais-possiveis- 
efeitos-do-coronavirus-sobre-o-meio-ambiente/amp/. Acesso em:30 de abr. de 2020.

QUAMMEN, D. Shaking the viral. Interview with David Q. Emergence Magazine, 15/04/2020.Disponível em: https://emergencemagazine.org/story/shaking-the-viral-tree/. Acesso em: 20 abr.2020.

QUANTO tempo o coronavírus sobrevive em cada superfície? SANARMED. Disponível em: https://www.sanarmed.com/quanto-tempo-o-coronavirussobrevive-em-cada-superficie-colunistas. Acesso em: 25 de maio de 2020.

SATO, M.; SANTOS, D.; SÁNCHEZ, C. Vírus: simulacro da vida? Rio de Janeiro: GEA-, UNIRIO / Cuiabá: GPEA, UFMT, 2020.

SATO, M. Educação Ambiental. São Carlos - SP: Rima, 2004.

SEMESP. O ensino superior no combate à COVID-19. Disponível em: $<$ https://www.semesp.org.br/ies-contra-a-covid-19/>. Acesso em: 23 de junho de 2020.

SILVA, J. L. L.; SOARES, R.; COSTA, F. S.; RAMOS, D. S.; LIMA, F. B.; TEIXEIRA, L. R. Fatores psicossociais e prevalência da síndrome de burnout entre trabalhadores de enfermagem intensivistas. Rev Brasileira de Terapia Intensiva. v.27, ํㅡ 2, p. 125-133, 2015.

TESINI, B. L. Coronavírus e síndromes respiratórias agudas (COVID-19, MERS 2 SARS). $2020 . \quad$ Disponível em:https://msdmanuals.com/pt/profissional/doencas-infecciosas/virusrespiratorios/coronavirus-e-sindromes-respiratorias-agudas-corid-19-mers-esars. Acesso em: 2 de maio de 2020.

UNIVERSIDADE DO ESTADO DA BAHIA. COVID-19: UNEB integra grupo de trabalho para produção de máscaras de proteção 3D para profissionais de saúde. Disponível em: https://portal.uneb.br/noticias/2020/03/25/uneb-integragrupo-de-trabalho-para-producao-de-mascaras-de-protecao-contra-covid-19para-profissionais-de-saude/. Acesso em: 13 de maio de 2020.

UNIVERSIDADE DO ESTADO DA BAHIA. UNEB convoca estudantes do internato de medicina para combate a COVID-19 em força-tarefa de telemedicina. Disponível em: https://portal.uneb.br/noticias/2020/03/20/unebconvoca-estudantes-do-internato-de-medicina-para-combate-ao-covid-19-emforca-tarefa-de-telemedicina/. Acesso em: 13 de maio de 2020.

UNIVERSIDADE FEDERAL DE JUIZ DE FORA/UFJF. Pandemia e Meio Ambiente: Impactos momentâneos ou nova normalidade?. Disponível em: https://www2.ufff.br/noticias/2020/04/24/pandemia-e-meio-ambiente-impactosmomentaneos-ou-nova-normalidade/. Acesso em: 30 de abr. de 2020. 